\title{
Genetic Fingerprinting of Bacillus thuringiensis Isolates by Randomly Amplified Polymorphic DNA Polymerase Chain Reaction (RAPD-PCR)
}

\author{
Gyan Sundar Sahukhal', Upendra Thapa Shrestha ${ }^{1}$, Binod Lekhak ${ }^{2}$, \\ Anjana Singh ${ }^{2}$, Viswanath Prasad Agrawal ${ }^{1}$ \\ ${ }^{1}$ Research Laboratory for Biotechnology and Biochemistry (RLABB), Kathmandu, Nepal \\ ${ }^{2}$ Central Department of Microbiology, Tribhuvan University, Kirtipur, Nepal \\ e-mail: gyan633413@gmail.com
}

\begin{abstract}
Random Amplified Polymorphic DNA (RAPD) is a method of producing a genetic fingerprint of a particular species without its prior genetic information. Relationship between species may be determined by comparing their unique fingerprint information. B. thuringiensis was isolated from soil samples of Khumbu base camp of Everest region, Nepal. Crystal protein (delta endotoxin) producing strains (46 from Phereche and 40 from Sagarmatha national park) were tested against a series of 100 decamer RAPD primers (codes 201-300, obtained from University of British Columbia) by RAPD PCR. Primer 284 was found the best among the tested primers and the reaction condition for PCR was optimized with a PCR buffer containing $10 \mathrm{mM}$ Tris $\mathrm{HCl}, 50 \mathrm{mM} \mathrm{KCl}, 3 \mathrm{mM} \mathrm{MgCl}_{2}$ with pH 8.3.; 200im dNTPs each, $1 \mathrm{U}$ Taq polymerase , 40 pmol decamer primers, $20 \mathrm{ng}$ template DNA and $1 \%$ DMSO as a final concentrations in $25 \mathrm{il}$ reaction mixture. The thermal programme was programmed as initial denaturation temperature at $94^{\circ} \mathrm{C}$ for $5 \mathrm{~min}$ followed by 35 cycles with denaturation at $94^{\circ} \mathrm{C}$ for $1 \mathrm{~min}$, annealing at $36^{\circ} \mathrm{C}$ for $1 \mathrm{~min}$ and extension at $72^{\circ} \mathrm{C}$ for 2 mins with final extension temperature at $72^{\circ} \mathrm{C}$ for $10 \mathrm{~min}$. Higher polymorphic fragments were found in the range between $700-900 \mathrm{bp}$. Next to it, the range of 400-700 and 1200-1600 bp were, too, highly polymorphic among the isolates. The discriminatory capacity (D) of the RAPD-PCR was found to be 0.9901 . The isolates of cold tolerant $B$. thuringiensis from high altitude regions were found rich in genomic polymorphism.
\end{abstract}

Key words: RAPD-PCR, fingerprint, endotoxin, Bacillus thuringiensis Berliner, polymorphism, base pair (bp)

\section{Introduction}

Use of chemical pesticides has led to the emergence and spread of resistance in agricultural pests and vectors of human diseases and to the environmental degradation. The very properties that made these chemicals useful-long residual action and toxicity to a wide spectrum of organisms-have brought about serious problems. An urgent need has thus emerged for environment friendly pesticides to reduce contamination and the likelihood of insect resistance (Ben-Dov et al. 1997).

The soil bacterium Bacillus thuringiensis Berliner fulfills the requisites of a microbiological control agent against agricultural pests and vectors of diseases that lead to its widespread commercial application. It is a gram- positive, aerobic, endospore-forming saprophyte. All known subspecies of $B$. thuringiensis produce large quantities of insecticidal crystal proteins (Cry proteins) which are segregated in parasporal bodies (also known as ä-endotoxins). The genes coding for Cry proteins normally occur on large plasmids and direct the synthesis of a family of related Cry proteins classified as Cry 1-28 and Cyt1-2 groups according to their degree of amino acid homology. Cry proteins have been used as biopesticide sprays on a significant scale for more than 30 years, and their safety has been demonstrated. The main target pest of $B$. thuringiensis include various lepidopterous (butterflies and moths), dipterous (flies and mosquitoes), and coleopterous (Beetles) species. Some strains have also been found 
to kill nematodes (Schenpf et al. 1998). Conventional $B$. thuringiensis preparations such as those registered in Germany and found worldwide are mostly derived from the highly potent strain $B$. thuringiensis var. kurstaki HD1, which was isolated in the sixties (Dulmage 1970).

Williams et al. (1990) used varieties of morphological and physiological characteristics to assign different bacterial strains into defined taxonomical clusters. However, most of the taxonomic methods are very time consuming and sometimes give ambiguous results. Genomic fingerprinting assays using RAPD have already been shown to be useful for differentiation of bacterial strains. This method is based on the amplification of distinct DNA sequences under low stringency conditions during annealing using an oligonucleotide of arbitrary sequence. The primer is not directed at any specific sequences within the template, making previous knowledge of the genome nonessential. The efficacy of the amplification procedure is primarily dependent on sufficient sequence similarity at the 3' end of the oligonucleotide to allow adequate priming. The resulting pattern of amplification products of varying size can subsequently be used as a genetic fingerprinting of the organisms (Mehling et al. 1995) and can also be used to genetically link to a trait of interest for individual and pedigree identification, pathogenic diagnostics, and trait improvement in genetics and breeding programmes. Morphological, biochemical characterization and identification, isozyme analysis, restriction fragment length polymorphism (RFLP), minisatellites, microsatellites, randomly amplified polymorphic DNAs (RAPD) and fluorescence in situ hybridization (FISH) have been so far used to analyse genetic similarity and diversity for breeding research of animal/plant/microbes (Yoon \& Kim 2001). In this study RAPD-PCR has been used for genetic and molecular studies as it is a simple and rapid method for determining genetic diversity and similarity in various organisms.

\section{Materials and Methods}

\section{Bacterial isolates}

B. thuringiensis were isolated by acetate selection method from the soil samples collected from Khumbu base camp of Everest region. The isolates were identified by standard microbiological techniques including colonial, morphological and biochemical characteristics according to Bergey's manual of systematic bacteriology (Claus \& Berkeley 1986).

\section{Preparation of template DNA}

Templates were prepared from 16 to $18 \mathrm{hr}$ cultures in Luria-Bertani medium as described by Ben-dov et al. (1997). Aliquots of 3 to $4.5 \mathrm{ml}$ were harvested by centrifugation and washed once in TES $(10 \mathrm{mM}$ Tris$\mathrm{HCl}$ of $\mathrm{pH} 8.0,1 \mathrm{mM}$ EDTA, $100 \mathrm{mM} \mathrm{NaCl}$ ), and the pellets were resuspended in $100 \mathrm{ml}$ of lysis buffer (25\% sucrose, $25 \mathrm{mM}$ Tris-HCl [pH 8.0], $10 \mathrm{mM}$ EDTA, $4 \mathrm{mg}$ of lysozyme per $\mathrm{ml}$ ). The cell suspension was incubated for $1 \mathrm{hr}$ at $37^{\circ} \mathrm{C}$. Further, DNA extraction was performed as described by Sambrook et al. (1989). Extracted DNAs were quantitated by spectrofluorometer and diluted up to $20 \mathrm{ng} \mathrm{DNA} / \mathrm{ul}$ in order to feed on the PCR reaction mixture.

\section{RAPD reaction}

One hundred RAPD primers (10-mers) of arbitrary sequence obtained from University of British Columbia, Canada, were screened for the ability to produce discriminatory polymorphisms. RAPD-PCR mixture was set up that contained 20-50 ng of genomic DNA, 40 pmol of primer, $1 \mathrm{U}$ of Taq polymerase (Bangalore GENEI.), $200 \mathrm{uM}$ (each) deoxynucleoside triphosphate, $10 \mathrm{mM}$ Tris- $\mathrm{Cl}$ ( $\mathrm{pH} 8.3$ ), $50 \mathrm{mM} \mathrm{KCl,} 3$ $\mathrm{mM} \mathrm{MgCl} 2$ and $1 \%$ DMSO. Each reaction mixture was overlaid with $25 \mathrm{ul}$ of mineral oil and amplified with a Perkin-Elmer Cetus DNA Thermal Cycler model TC-1 as follows: (i) Initial denaturation, 1 cycle consisting of $5 \mathrm{~min}$ at $94^{\circ} \mathrm{C}$ and (ii) 35 cycles, with 1 cycle consisting of $1 \mathrm{~min}$ at $94^{\circ} \mathrm{C}, 2 \mathrm{~min}$ at $36^{\circ} \mathrm{C}$, and $3 \mathrm{~min}$ at $72^{\circ} \mathrm{C}$, followed by a final extension step at $72^{\circ} \mathrm{C}$ for $10 \mathrm{~min}$.

RAPD products were separated by agarose gel electrophoresis $(1 \%)$ with $1 \mathrm{X}$ TAE buffer for $2 \mathrm{hrs}$. Molecular size standards ( $\lambda$ DNA HindIII digest and $\phi X 174$ phage DNA type II digest) were also included in each gel, photographed by the Fototdyne camera using polaroid film (Porplan 667). The RAPD fingerprints were analyzed visually and the molecular size of each band migrated was calculated by plotting standard curve (log of molecular weight vs distance travelled) of the standard DNA ladders.

\section{Results}

Ninety one soil samples collected from the Khumbu base camp of Everest region, Nepal were processed at Research Laboratory for Biotechnology and Biochemistry. A total 109 B. thuringiensis isolates 
Gyan Sundar Sahukhal et al./Genetic Fingerprinting of Bacillus......

were obtained from the soil samples of Phereche (P) and Sagarmatha national park (SNP). From 52 Phereche soil samples, 63 isolates were obtained and from 39 soil samples from SNP, 46 isolates were obtained but only 86 isolates were found to produce crystal protein which were preceded for RAPD-PCR (Shrestha et al. 2006)

\section{Identification of discriminatory primer(s) for RAPD analysis}

Nine primers (Table 1) with GC content - 50-80\%, were found to amplify genomic DNA fragments with reproducible polymorphisms suitable for strain differentiation of the $B$. thuringiensis isolates (Fig 1). Primer 284 with GC content $70 \%$ was found to produce more polymorphic bands than other primers and was used to obtain RAPD profiles of some selected B. thuringiensis isolates (Fig 2 and 3).

Table 1. RAPD primers producing reproducible polymorphisms with $B$. thuringiensis

\begin{tabular}{|c|c|c|c|c|c|}
\hline S.No & Primer & $\begin{array}{l}\text { Sequences } \\
\text { of primers } \\
\text { (5' to 3') }\end{array}$ & $\begin{array}{c}\mathrm{GC} \% \\
\text { of } \\
\text { primers }\end{array}$ & $\begin{array}{c}\text { No. of } \\
\text { bands } \\
\text { produced }\end{array}$ & $\begin{array}{l}\text { Molecular size of the bands } \\
\text { (bp) }\end{array}$ \\
\hline 1 & 208 & ACGGCCGACC & 80 & 8 & $2821,1842,1473,1282,747,639,502,357$ \\
\hline 2 & 254 & CGC CCC CATT & 70 & 6 & $4228,3102,2357,1125,789,639$ \\
\hline 3 & 256 & TGCAGT CGAA & 50 & 2 & 1125,372 \\
\hline 4 & 268 & AGGCCGCTTA & 60 & 6 & $2575,1583,1282,936,789,404$ \\
\hline 5 & 275 & CCGGGCAAGC & 80 & 8 & $4228,2575,1282,993,789,672,526,372$. \\
\hline 6 & 276 & AGGATCAAGC & 50 & 7 & $2357,1473,1282,1056,936,747,639$ \\
\hline 7 & 284 & CAGGCGCACA & 70 & 10 & $3425,1995,1583,1373,1200,936,834,747,639,480$ \\
\hline 8 & 292 & AAA CAGCCC G & 60 & 3 & $1373,993,708$ \\
\hline 9 & 299 & TGTCAGCGGT & 60 & 2 & 1373,993 \\
\hline
\end{tabular}

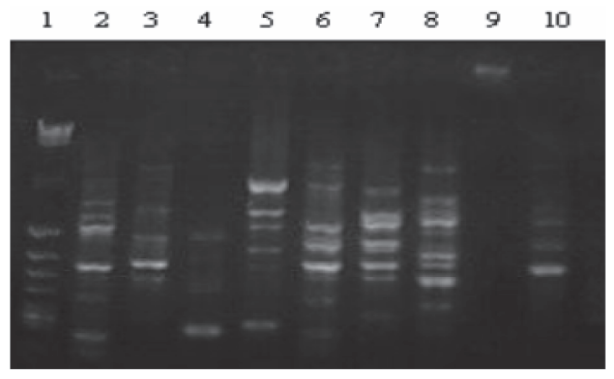

Fig 1: Screening of Primers producing reproducible polymorphisms. Lane 1: DNA marker $\lambda$-DNA/HinII digest, Lane 2-10: primer 208, 254, 256, 268, 275, $276,284,292$ and 299 respectively.

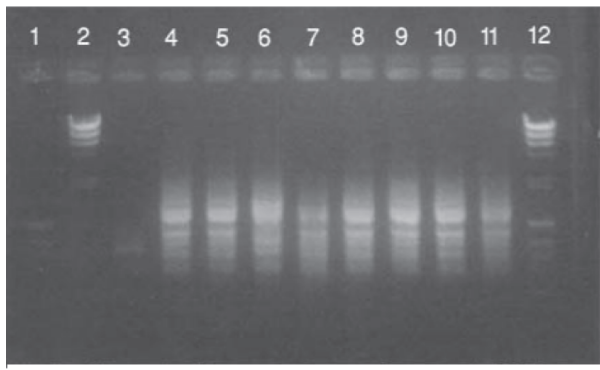

Fig 3: RAPD profiles of different B. thuringiensis isolates Lane 1,2 \&12-Molecular size marker ( $\varphi 174$ HaeIII cut, $\lambda$ DHA HinII cut Mixed molecular size markers. Lane $3-11, \mathrm{P}_{44}, \mathrm{P}_{45}, \mathrm{P}_{46}, \mathrm{~F}_{489}, \mathrm{P}_{49}, \mathrm{P}_{50}$, $\mathrm{P}_{51 \mathrm{~b}}, \mathrm{P}_{52}$ and $\mathrm{P}_{53}$ respectively.

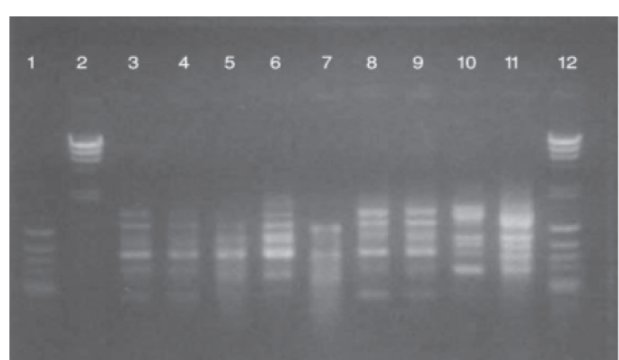

Fig 2: RAPD profiles of different $B$. thuringiensis isolates Lane 1, 2 \&12-Molecular size marker ( 174 HaeII cut, $\lambda$ DNA Hin II cut Mixed molecular size markers. Lane 3-5, $\mathrm{P}_{34}$, Lane 6-11, $\mathrm{P}_{37}, \mathrm{P}_{38}, \mathrm{P}_{39}, \mathrm{P}_{39}, \mathrm{P}_{42}$ and $\mathrm{P}_{43}$ respectively. 
Of 108 isolates, 86 , the crystal protein producers, were typed by RAPD-PCR to study the polymorphism patterns. The RAPD typing results are summarized in Table 2, 3 and 4 .

\section{RAPD fingerprinting of the $B$. thuringiensis isolates}

Table 2. RAPD types of the Phereche isolates

\begin{tabular}{|c|c|c|c|}
\hline S.No & Codes of theisolates & $\begin{array}{l}\text { No. of RAPD } \\
\text { bands produced }\end{array}$ & Number of the base pairs (bp) \\
\hline 1 & $\mathrm{P}_{1}$ & 1 & 2061 \\
\hline 2 & $\mathrm{P}_{2}$ & 1 & 812 \\
\hline 3 & $\mathrm{P}_{3}$ & 6 & $1843,1563,1213,962,690,495$. \\
\hline 4 & $\mathrm{P}_{5}$ & 4 & $1563,1053,811,690$ \\
\hline 5 & $\mathrm{P}_{6}$ & 2 & 1274,811 \\
\hline 6 & $\mathrm{P}_{7}$ & 7 & $1378,788,738,692,611,512$ \\
\hline 7 & $\mathrm{P}_{9 \mathrm{a}}$ & 10 & $2061,1436,1270,1173,1046,937,815,738,692,630$ \\
\hline 8 & $\mathrm{P}_{10}$ & 1 & 1563 \\
\hline 9 & $\mathrm{P}_{12 \mathrm{a}}$ & 6 & $2139,1944,1629,1501,1337,1200$ \\
\hline 10 & $\mathrm{P}_{12 \mathrm{~b}}$ & 1 & 2497 \\
\hline 11 & $\mathrm{P}_{13}$ & 6 & $1648,1449,1187,1023,889,775$ \\
\hline 12 & $\mathrm{P}_{14}$ & 1 & 1499 \\
\hline 13 & $\mathrm{P}_{15}$ & 5 & $3148,2638,1944,1389,927$ \\
\hline 14 & $\mathrm{P}_{17 \mathrm{~b}}, \mathrm{P}_{25}, \mathrm{P}_{27}, \mathrm{P}_{28}, \mathrm{P}_{30}$ & 2 & 1944,1501 \\
\hline 15 & $\mathrm{P}_{18}$ & 6 & $2368,2139,1775,1629,1501,1200$ \\
\hline 16 & $\mathrm{P}_{21}$ & 1 & 1629 \\
\hline 17 & $\mathrm{P}_{22}$ & 6 & $3353,2638,2139,1050,1289,1121$ \\
\hline 18 & $\mathrm{P}_{24}$ & 2 & 2139,1700 \\
\hline 19 & $\mathrm{P}_{26}$ & 2 & 2249,1944 \\
\hline 20 & $\mathrm{P}_{29}$ & 3 & $2638,1944,1501$ \\
\hline 21 & $\mathrm{P}_{31}$ & 3 & $1086,670,527$ \\
\hline 22 & $\mathrm{P}_{32}$ & 1 & 1501 \\
\hline 23 & $\mathrm{P}_{33}$ & 4 & $1156,921,811,551$ \\
\hline 24 & $\mathrm{P}_{34}$ & 5 & $1553,1326,763,567,375$ \\
\hline 25 & $\mathrm{P}_{35}$ & 10 & $1499,1378,1128,972,873,788,738,692,542,512$ \\
\hline 26 & $\mathrm{P}_{37}$ & 7 & $2006,1553,1229,991,717,508,413$ \\
\hline 27 & $\mathrm{P}_{38}$ & 3 & $1142,717,567$ \\
\hline 28 & $\mathrm{P}_{39}$ & 6 & $1553,1229,991,763,600,375$ \\
\hline 29 & $\mathrm{P}_{40}$ & 10 & $2804,2393,1874,1635,1322,1128,937,844,738,670$ \\
\hline 30 & $\mathrm{P}_{41}$ & 5 & $1483,1274,962,718,571$ \\
\hline 31 & $\mathrm{P}_{42}$ & 6 & $1837,1433,991,867,717,567$ \\
\hline 32 & $\mathrm{P}_{43}$ & 5 & $1229,926,812,717,636$ \\
\hline 33 & $\mathrm{P}_{45}$ & 5 & $1378,1173,844,738,512$ \\
\hline 34 & $\mathrm{P}_{46}$ & 4 & $1229,867,717,567$ \\
\hline 35 & $\mathrm{P}_{47}$ & 4 & $2638,2368,2139,1775$ \\
\hline 36 & $\mathrm{P}_{48 \mathrm{a}}$ & 5 & $1229,926,812,675,567$ \\
\hline 37 & $\mathrm{P}_{44}, \mathrm{P}_{49}, \mathrm{P}_{50}, \mathrm{P}_{51 \mathrm{~b}}, \mathrm{P}_{52}$ & 5 & $1229,991,867,763,636$ \\
\hline 38 & $\mathrm{P}_{53}$ & 4 & $2368,2038,1775,1443$ \\
\hline
\end{tabular}


Table 3. RAPD types of the SNP isolates

\begin{tabular}{|c|c|c|c|}
\hline SNo & Codes of theisolates & $\begin{array}{l}\text { No. of } \\
\text { RAPDb } \\
\text { ands } \\
\text { produced }\end{array}$ & Number of the base pairs (bp) \\
\hline 1 & $\mathrm{~S}_{1}$ & 5 & $2291,1811,1409,787,465$ \\
\hline 2 & $\mathrm{~S}_{2}^{1}$ & 5 & $2079,1733,1355,787,465$ \\
\hline 3 & $\mathrm{~S}_{2 \mathrm{~b}}^{2 \mathrm{a}}$ & 3 & $1409,1087,477$ \\
\hline 4 & $\mathrm{~S}_{3}^{2 b}$ & 8 & $1255,1074,962,807,706,663,520,417$ \\
\hline 5 & $\mathrm{~S}_{4}^{3}$ & 6 & $1723,1512,1283,1187,953,755$ \\
\hline 6 & $\mathrm{~S}_{5}^{4}$ & 8 & $1792,1656,1534,1235,1012,893,817,771$ \\
\hline 7 & $\mathrm{~S}_{6}^{5}, \mathrm{~S}_{7}$ & 5 & $1361,1074,754,464,375$ \\
\hline 8 & $\mathrm{~S}_{8}^{6^{\prime}}$ & 7 & $1764,1419,754,684,586,395,339$ \\
\hline 9 & $\mathrm{~S}_{10}^{8}$ & 10 & $3793,2181,1733,1466,1256,1087,950,867,701,538$ \\
\hline 10 & $\mathrm{~S}_{13}^{10}$ & 4 & $1733,1466,891,787$ \\
\hline 11 & $\mathrm{~S}_{14}^{13}$ & 5 & $950,787,701,628,512$ \\
\hline 12 & $\mathrm{~S}_{15 \mathrm{a}}^{14}$ & 11 & $1983,1591,1355,1167,982,891,837,787,701,663,448$ \\
\hline 13 & $\mathrm{~S}_{15 \mathrm{~b}}^{10 \mathrm{a}}$ & 5 & $1304,1087,891,742,663$ \\
\hline $\begin{array}{l}14 \\
15\end{array}$ & $\mathrm{~S}_{16}^{100}$ & 6 & $2291,1894,1466,1256,787,701$ \\
\hline 16 & $\mathrm{~S}_{\mathrm{S}^{20}}$ & $\begin{array}{l}4 \\
4\end{array}$ & $\begin{array}{l}807,586,339,294 \\
706,586,440,280\end{array}$ \\
\hline 17 & $\mathrm{~S}_{23}^{21}$ & 4 & $1594,1431,601,473$ \\
\hline 18 & $\mathrm{~S}_{24}^{23}$ & 3 & $930,726,647$ \\
\hline 19 & $\mathrm{~S}_{25}^{24}$ & 5 & $2277,1170,819,755,522$ \\
\hline 20 & $\mathrm{~S}_{2}^{25}$ & 5 & $2776,1154,980,794,519$ \\
\hline 21 & $\mathrm{~S}_{27}^{26}$ & 7 & $1170,930,819,560,505,443,320$ \\
\hline 22 & 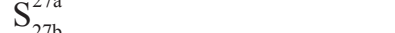 & 5 & $1784,1431,1291,891,392$ \\
\hline 23 & $\mathrm{~S}_{28}^{2 / 0}$ & 8 & $2990,2009,1784,1431,1291,972,891,647$ \\
\hline 24 & $\mathrm{~S}_{28 \mathrm{~b}}^{28 \mathrm{a}}$ & 8 & $1594,1359,1229,1017,930,726,624,458$ \\
\hline 25 & $\mathrm{~S}_{30}^{200}$ & 8 & $1866,1235,1080,893,794,709,603,545$ \\
\hline 26 & $\mathrm{~S}_{31}$ & 10 & $2028,1593,1325,1235,1080,980,841,709,653,519$ \\
\hline $\begin{array}{l}21 \\
28\end{array}$ & $\mathrm{~S}_{32}$ & $\begin{array}{l}8 \\
5\end{array}$ & $1288,1049,866,791,694,638,588,433$ \\
\hline 29 & $\mathrm{~S}_{35 \mathrm{~b}}^{33}$ & 7 & $1103,908,791,665,638,565,433$ \\
\hline 30 & $\mathrm{~S}_{37}^{35 b}$ & 6 & $908,791,638,565,466,433$ \\
\hline 31 & $\mathrm{~S}_{38 \mathrm{~b}}^{37}$ & 5 & $1648,1449,1234,1101,953$ \\
\hline 32 & $\mathrm{~S}_{39}^{38 \mathrm{~b}}$ & 5 & $1222,999,757,543,403$ \\
\hline 33 & $\mathrm{~S}_{41}$ & 1 & 1283 \\
\hline 34 & $\mathrm{~S}_{9}, \mathrm{~S}_{18}, \mathrm{~S}_{22}, \mathrm{~S}_{34}, \mathrm{~S}_{35 \mathrm{a}}, \mathrm{S}_{36}, \mathrm{~S}_{38 \mathrm{a}}$ & & No RAPD bands produced \\
\hline
\end{tabular}

Table 4. Fragment length polymorphisms among the total

\section{B. thuringiensis isolates}

\begin{tabular}{l|c|l|c}
\hline $\begin{array}{c}\text { Range of fragment } \\
\text { length (bp) }\end{array}$ & $\begin{array}{c}\text { Total number of bands } \\
\text { produced }\end{array}$ & $\begin{array}{c}\text { Range of fragment } \\
\text { length (bp) }\end{array}$ & $\begin{array}{c}\text { Total number of bands } \\
\text { produced }\end{array}$ \\
\hline $200-300$ & 2 & $1700-1800$ & 12 \\
$300-400$ & 9 & $1800-1900$ & 6 \\
$400-500$ & 25 & $1900-2000$ & 10 \\
$500-600$ & 23 & $2000-2100$ & 7 \\
$600-700$ & 34 & $2100-2200$ & 6 \\
$700-800$ & 50 & $2200-2300$ & 4 \\
$800-900$ & 46 & $2300-2400$ & 4 \\
$900-1000$ & 21 & $2500-2500$ & 1 \\
$1000-1100$ & 17 & $2600-2600$ & 4 \\
$1100-1200$ & 13 & $2700-2800$ & 1 \\
$1200-1300$ & 32 & $2800-2900$ & 1 \\
$1300-1400$ & 14 & $3100-3200$ & 1 \\
$1400-1500$ & 17 & $3300-3400$ & 1 \\
$1500-1600$ & 20 & $3700-3800$ & 1 \\
$1600-1700$ & 8 & & \\
\hline
\end{tabular}




\section{Calculation of discriminatory index value (D)}

Of 86 isolates typed, 72 different polymorphics were found. The discriminatory index value (D) was calculated using the formula:

$$
D=1-\frac{1}{N(N-1)} \sum_{j=1}^{s} x_{j}\left(x_{j}-1\right)
$$

The D value was found to be 0.9901 .

\section{Discussion}

All the soil samples in this study were collected from high altitude mountain area - Khumbu base camp of Everest region, Nepal expecting mainly cold tolerating strains of $B$. thuringiensis. The genome of each $B$. thuringiensis is unique and is basic to all DNA analysis aimed at identification (Belkum et al. 1994). Based on this assumption RAPD-PCR was optimized to study genetic diversity of the $B$. thuringiensis isolates from Khumbu region of Nepal. As RAPD-PCR has higher discrimination power than any other conventional techniques (Lechner et al.1998, Daffonchio et al. 1999, Robert \& Crawford 2000, Brousseau et al. 1993, PuentiRedondo et al. 1999) and opens a new horizon with reproducible data, it is considered as a doorway for any genetic analysis to perform. RAPD assay resulted in a clear separation of the psychrotolerant $B$. cereus strains (Lechner et al. 1998).

A series of 100 decamer primers from codes 201 to 300 (obtained from UBC) were tested for RAPD-PCR. It has been shown that the optimal length of primers used in RAPD analysis is approximately eight nucleotides. Primers longer than 10 nucleotides have less discriminating power, which again is strongly dependant on the annealing temperature (Belkum 1994). Nine primers, with $\mathrm{GC} \%$ of 50-80, were found to amplify the target sequences with reproducible polymorphism to differentiate the $B$. thuringiensis strains. The primers with high GC content (70-80\%) were found to produce more polymorphisms compared to those of low GC content (50-60\%). PCR products are visualized by ethidium bromide staining (0.2-0.5 ig/ml of gel) of electrophoretically separated DNA in agarose gel. Fingerprints are recorded as banding patterns and comparisons made by visual inspections using standard scales. Standard molecular markers ( $\lambda$ DNA Hind III digest and $\phi$ X 174 phage DNA type II digest) were used. Each primer amplified polymorphisms ranged from two to ten over a range of $300 \mathrm{bp}$ to $3 \mathrm{kbps}$. The bands were found reproducible for different independent DNA preparations from respective $B$. thuringiensis strains.

Each primer yielded RAPD patterns that were unique to strains of the $B$. thuringiensis isolates to be differentiated subsequently. Primer 284 from the series was selected best to type the $B$. thuringiensis isolates for polymorphic study. Of the total amplified products, maximum number of the product size ranged from $300 \mathrm{bp}$ to $2 \mathrm{~kb}$; with highest number of 50 bands within 700 to $800 \mathrm{bp}$, followed by 46 bands within 800 to $900 \mathrm{bp}, 34$ bands within 600 to 700 bp and 32 bands within 1200 to $1300 \mathrm{bp}$. Similar band patterns suggest that the strains are closely related to each other within each group. However, the data must be interpretative with caution since PCR bands of similar size do not necessarily mean that the molecules are identical in sequence (Brousseau et al.1993). As the strains were isolated from high altitude mountain region of the country, the maximum amplified genomes may represent cold tolerant genes common to all or the crystal endotoxin producing genes. However, for the best knowledge, such study for cold tolerance was not found yet and the data were not compared to any reference but predicted to contain common or consensus bands (or may be sequences) for cold tolerance so as to adopt the organisms in a given ecological niche.

Vogel et al. (1999) tested the usefulness of genomic typing methods viz. RAPD analysis and ribotyping with conventional serotyping for three collections of well defined clinical $E$. coli isolates and found that RAPD had the highest discriminatory capacity. In order to determine the index of discrimination (Hunter 1990, Hunter \& Gaston 1998), all the $86(N)$ crystal producing $B$. thuringiensis strains were classified into 71 $(s)$ types with two sets of five similar band patterns $\left(\mathrm{n}_{14}\right.$ and $\left.\mathrm{n}_{37}\right)$, one set of two similar band pattern $\left(\mathrm{n}_{45}\right)$ and 68 sets of a single band pattern $\left(\mathrm{n}_{1}\right.$ $\mathrm{n}_{13}, \mathrm{n}_{15}-\mathrm{n}_{36}, \mathrm{n}_{38}-\mathrm{n}_{44}$, and $\left.\mathrm{n}_{46}-\mathrm{n}_{71}\right)$. Altogether six $B$. thuringiensis isolates were not found to contain amplifying region in their genome using 284 primers and were classified in the 72 nd type as $n_{72}$.

The RAPD-PCR, used to categorize the $B$. thuringiensis strains isolated from Khumbu region of Nepal, was found to discriminate the organisms with $99.01 \%$ confidence $(\mathrm{D}=0.9901)$. The level of confidence satisfied the conclusion made by Vogel et al. (1999) to define RAPD analysis had the highest discriminatory capacity for typing E. coli isolates. Similarly, while working for RAPDtyping of Pseudomonas aeruginosa from cystic fibrosis 
patients, Mahenthiralingam et al. (1996) stated that, in general, despite alteration in the expression of mucoid exopolysaccharide, bacterial motility, and acquisition of a serum-sensitive phenotype, the RAPD fingerprints of sequential isolates remain stable, suggesting that these changes result from phenotypic adaptation of the primary colonizing isolates. With these findings, the polymorphisms set by RAPD to quantify the diversity of $B$. thuringiensis strain isolates from Khumbu region of Nepal can be confidently defined as rich one.

\section{Acknowledgement}

The authors express full gratitude to CNR (Italy's National Research Council) for supporting this work; to Dr. Deepak Singh, Dr.Yogan Khatri and Dr. Rajindra Aryal for soil sample collection from the Everest region; and to Mr. Kiran Babu Tiwari for his sincere efforts and suggestions.

\section{References}

Belkum, A. 1994. DNA fingerprinting of medically important microorganisms by use of PCR. Clinical Microbiology Reviews 7: 174-184.

Ben-Dov, E., A. Zaritsky, E. Dahan, Z. Barak, R. Sinai, R. Manasherob, A. Khamraev, E. Troitskaya, A. Dubitsky, N. Berezina and Y. Margalith. 1997. Extended screening by PCR for seven cry-group genes from field-collected strains of Bacillus thuringiensis. Appl. Environ. Microbiol. 63: 4883-4890.

Brousseau, R., A. Saint-Onge, G. Prefontaine, L. Masson and J. Cabana. 1993. Arbitrary primer polymerase chain reaction, a powerful method to identify Bacillus thuringiensis serovars and strains. Applied and Environmental Microbiology. 59: 114-119.

Claus, D. and R.W.C. Berkeley. 1986. Genus Bacillus Cohn 1872. In Bergey's. Manual of Systematic Bacteriology Vol. 2. (ed. Sneath, P.H.A.) Baltimore, M.D: Williams \& Wilkins. pp. 1105-1138

Daffonchio, D., S. Borin, G. Frova, R. Gallo, E. Mori, R. Fani and C. Sorlini. 1999. A randomly amplified polymorphic DNA marker specific for the Bacillus cereus group is diagnostic for Bacillus anthracis. Appl. Environ. Microbiol. 65: 1298-1303.

Dulmage, H.T. 1970. Production of spore-delta-endotoxin complex by variants of Bacillus thuringiensis in two fermentation media. Journal of Invertebrate Patholog 16: 385-389.

Hunter, P.R. 1990. Reproducibility and indices of discriminatory power of microbial typing methods. Journal of Clinical Microbiolog 28: 1903-1905.

Hunter, P.R. and M.A. Gaston. 1988. Numerical index of the discriminatory ability of typing systems: an application of simpson's index of diversity. Journal of Clinical Microbiolog 26: 2465-2466.

Lechner, S., R. Mayr, K.P. Francis, B.M. Pruss, T. Kaplan, E. Wiessner-Gunkel, G.S. Stewart and S. Scherer. 1998. Bacillus weihenstephanensis sp. nov. is a new psychrotolerant species of the Bacillus cereus group. International Journal of Systematic Bacteriolog 48 (4): 1373-1382.

Mahenthiralingam, E., M.E. Campell, J. Foster, J.S. Lam and D.P. Speert. 1996. Random amplified polymorphic DNA typing of Pseudomonas aeruginosa isolates recovered from patients with cystic fibrosis. Journal of Clinical Microbiology. 34: 1129-1135.

Martin, P.A. and R.S. Travers. 1989. Worldwide abundance and distribution of Bacillus thuringiensis isolates. Appl. Environ. Microbiol 55: 2437-2442.

Mehling, A., U.F. Wehmeier and W. Pieperberg. 1995. Application of random amplified polymorphic DNA (RAPD) assays in identifying consercer regions of actinomycete genomes. FEMS microbiol. Lett. 128: 119-126.

Puente-Redondo, V.A., N.G. Blanco, C.B. Gutierrez-Martin, F.J. Garcia-Pena and E.F.R. Ferri 2000. Comparision of different PCR approaches for typing of Francisella tularensis strains. Journal of Clinical Microbiology 38: 1016-1022

Roberts, M.A. and D.L. Crawford. 2000. Use of randomly amplified polymorphic DNA as a means of developing genus- and strain-specific Streptomyces DNA probes. Applied and Environmental Microbiology 66:2555-2564.

Sambrrok, J., E.F. Fritsch, T. Maniatis. 1989. Molecular cloning: A laboratory manual. ( $\left.2^{\text {nd }} \mathrm{Ed}\right)$. cold spring harbor laboratory press, Cold Spring Harbor, New York

Schnepf, E., N. Crickmore, J. Van Rie, D. Lereclus, J. Baum, J. Feitelson, D.R. Zeigler and D.H. Dean. 1998. Bacillus thuringiensis and its pesticidal crystal proteins. Microbiology and Molecular Biololgy Reviews 62: 775806.

Shrestha, U.T., G.S. Sahukhal, S. Pokharel, K.B. Tiwari, A. Singh and V.P. Agrawal. 2006. Delta endotoxin immunocrossreactivity of Bacillus thuringiensis isolates collected from Khumbu base camp of Mount Everest region. Journal of Food Science Technology Nepal 2: 128-131.

Vogel, L, E. HMM, M. Mindehoud and L. Dijkshoom. 1999. Epidemiologic typing of Escherichia coli using RAPD analysis, ribotyping and serotyping. Journal of Clinical Microbiology 6: 82-87.

Yoon, J.M. and G.W. Kim. 2001. Randomly amplified polymorphic DNA-polymerase chain reaction analysis of two different populations of cultured Korean catfish Silurus asotus. Indian Academy of Sciences 26: 641-647.

Williams, J.G.K., A.R. Kubelik, K.J. Livak, J.A. Rafalski, S.V. Tingey. 1990. DNA polymorphisms amplified by arbitrary primers are useful as genetic markers. Nucleic Acids Research 18: 6531-6535. 
Nepal Journal of Science and Technology 10 (2009) 